\title{
Pengaruh Penambahan Konsentrasi Tepung Tapioka Terhadap Komposisi Gizi dan Evaluasi Sensori Nugget Daging Merah Ikan Madidihang
}

\author{
Vanessa Natalie Jane Lekahena* \\ Staf Pengajar Prodi THP FAPERTA UMMU-Ternate, Email: enchalekahena@yahoo.com
}

\begin{abstract}
ABSTRAK
Nugget ikan adalah olahan daging ikan yang digiling halus yang dicampur dengan bahan pengikat dan bumbu lainnya, kemudian dikukus dan dicetak sesuai bentuk yang diinginkan. Daging merah ikan adalah bagian daging yang biasanya dibuang dan kurang disukai karena berbau amis dan tengik. Pemanfaatan daging merah ikan madidihang menjadi nugget merupakan bentuk diversifikasi olahan. Proses pembuatan nugget membutuhkan bahan pengikat berupa tepung sehingga menghasilkan produk dengan mutu yang baik. Tujuan penelitian ini adalah untuk mengetahui pengaruh penambahan konsentrasi tepung tapioka terhadap komposisi gizi dan evaluasi sensori nugget daging merah ikan madidihang. Komposisi gizi nugget ikan menunjukkan bahwa makin besar penambahan konsentrasi tepung tapioka yang digunakan dalam pembuatan nugget ikan meningkatkan nilai kadar air (48.98-54.58\%) dan karbohidrat (16.46-19.95\%) tetapi menurunkan kadar protein (13.71-17.61\%), abu (1.98-4.49\%) dan lemak (9.78-12.46\%), sementara evaluasi sensori menunjukkan bahwa penambahan konsentrasi tepung tapioka berpengaruh nyata terhadap atribut tekstur, warna, dan aroma, tetapi tidak berpengaruh terhadap atribut rasa nugget.
\end{abstract}

Kata Kunci : Daging merah ikan, evaluasi sensori, gizi, tapioka

\section{PENDAHULUAN}

Ikan merupakan salah satu sumber protein yang mengandung asam amino esensial dengan nilai biologis tinggi dan memiliki harga murah jika dibandingkan dengan sumber protein lainnya, namun, daging ikan mudah membusuknya. Sehingga perlu upaya penanganan, pengolahan, dan pengawetan untuk mencegah kerusakan dan memperpanjang daya simpan.

Ikan madidihang (Thunnus albacares) adalah jenis ikan ekonomis penting yang potensial di wilayah Maluku Utara. Jenis ikan ini umumnya diolah dan dipasarkan dalam bentuk produk mentah, bahan setengah jadi atau produk siap saji. Salah satu hasil olahannya adalah tuna loin beku yang dalam proses pembuatannya menghasilkan limbah padat. Total keseluruhan limbah padat hasil pengolahan ikan sebesar $20-30 \%$ dari total keseluruhan ikan, berupa tulang ikan, sirip, kulit dan daging merah (Kim \& Mendis, 2006).

Daging merah ikan merupakan bahan tidak terpakai yang sering dibuang atau hanya digunakan sebagai bahan campuran pakan ternak. Rendahnya pemanfaatan daging merah ikan karena bau amis dan tengik daging tersebut, sehingga kurang disukai konsumen. Daging merah ikan adalah lapisan daging berpigmen kemerahan mengandung hemoprotein tinggi yang tersusun dari protein miosin, globin dan struktur heme (mioglobin dan hemoglobin), yang merupakan senyawa bersifat peroksidan dan lemak tinggi (Learson dan Kaylor, 1990; Amrullah, 2000). Kadar mioglobin daging merah ikan sekitar 9650.12 $\mathrm{mg} / \mathrm{kg}$ (Sánchez-Zapata et al., 2011).

Pemanfaatan daging merah ikan madidihang sebagai bahan baku nugget merupakan bentuk diversifikasi olahan yang bertujuan untuk meningkatkan nilai 
ekonomisnya. Nugget ikan adalah olahan daging ikan yang digiling halus yang dicampur dengan bahan pengikat dan bumbu lainnya, kemudian dikukus dan dicetak sesuai bentuk yang diinginkan, sedangkan menurut SNI (2013) nugget ikan adalah produk olahan menggunakan lumatan daging ikan (surimi) minimum $30 \%$ di campur tepung dan bahan lainnya dibalur dengan tepung pengikat dicelup ke dalam adonan batter mix di lapisi tepung roti dan dimasak.

Tepung tapioka biasanya digunakan dalam pembuatan nugget dan berfungsi sebagai bahan pengikat. Tepung tapioka adalah granula pati dari umbi ketela pohon yang kaya akan karbohidrat. Tepung tapioka mempunyai kandungan amilopektin yang tinggi sehingga mempunyai sifat tidak mudah menggumpal, mempunyai daya lekat yang tinggi, tidak mudah pecah atau rusak dan suhu gelatinisasinya relatif rendah antara 52-64 步C (Tjokroadikoesomo, 1993). Kandungan gizi tepung tapioka per $100 \mathrm{~g}$ sampel adalah $362 \mathrm{kal}$ protein $0.59 \%$, lemak $3.39 \%$, air $12.9 \%$ dan karbohidrat $\quad 6.99 \% \quad$ (Sediaoetomo, 2004). Penggunaan bahan pengikat bertujuan untuk membantu proses gelatinisasi, sehingga menghasilkan produk dengan nilai sensori yang baik dan dapat mempengaruhi komposisi gizi nugget yang dihasilkan.

Penelitian ini bertujuan untuk mengetahui pengaruh penambahan konsentrasi tepung tapioka terhadap komposisi gizi dan evaluasi sensori nugget daging merah ikan madidihang. Hasil penelitian ini diharapkan bermanfaat sebagai sumber informasi bagi nelayan pengolah hasil perikanan dalam mengolah limbah hasil pengolahan ikan madidihang menjadi produk yang bernilai ekonomis dan bergizi.

\section{Metode Penelitian}

\subsection{Alat dan Bahan}

Peralatan yang digunakan untuk pembuatan nugget adalah: pisau, grinder, blender, talenan, baskom plastik, panci perebusan, kompor, timbangan, spatula pengaduk, panci penggorengan dan sendok penyaring. Peralatan untuk analisis digunakan oven vakum, furnace, timbangan analitik, desikator, tang penjepit, cawan porselen, labu destilasi, peralatan ekstraksi, destruksi dan titrasi, serta alat lainnya sesuai dengan prosedur analisis sampel.

Bahan yang digunakan untuk pembuatan nugget ikan adalah daging merah ikan madidihang, garam, merica, bawang merah, bawang putih, tepung tapioka, air, minyak nabati, tepung roti dan telur. Sementara bahan kimia yang digunakan untuk analisis proksimat adalah $\mathrm{H} 3 \mathrm{BO} 3, \mathrm{~K} 2 \mathrm{SO} 4$, akuades, $\mathrm{HCl}$, heksan, $\mathrm{H} 2 \mathrm{SO} 4, \mathrm{NaOH}-\mathrm{Na} 2 \mathrm{~S} 2 \mathrm{O} 3$, dan larutan lainnya sesuai dengan prosedur analisis sampel.

\subsection{Persiapan Sampel}

Persiapan bahan baku, daging merah ikan tuna dicuci bersih untuk menghilangkan kotoran, darah dan lendir yang masih menempel pada daging ikan, selanjutnya dilumatkan menggunakan grinder menjadi daging lumat, selanjutnya dilakukan proses pencucian ke-2 menggunakan larutan $\mathrm{NaCl}$ $\mathbf{2 . 0 \%}$, ditiris dan disaring untuk pemisahan daging dan larutan. Proses pencucian menggunakan larutan $\mathrm{NaCl}$ bertujuan untuk melarutkan protein sarkoplasma, sehingga mempermudah proses pembentukan gel daging ikan pada saat proses pemasakan (Suzuki, 1981).

Pembuatan nugget ikan, daging merah lumat dicampurkan dengan bumbu-bumbu dan tepung tapioka dengan perlakuan sebagai berikut: A1 (0\% tepung tapioka), A2 (5\% tepung tapioka), A3 (10\% tepung tapioka), dan A4 (15\% tepung tapioka), selanjutnya dihomogenasi dan diaduk hingga menjadi adonan. Adonan kemudian dicetak dan dikukus pada suhu 100 $\stackrel{-5}{ } \mathrm{C}$, selama 30 menit hingga matang, kemudian didinginkan dan dilapisi putih telur dan tepung roti, sebelum digoreng dengan minyak nabati pada suhu $\pm 100 \stackrel{2}{2}$ C selama 60 detik.

\subsection{Prosedur Analisis}

\subsubsection{Kadar Air (SNI 01-2354.2-2006)}

Cawan porselin kosong dipanaskan dalam oven pada suhu $100{ }^{\circ} \mathrm{C} \pm 30$ menit, didinginkan dalam desikator $\pm \mathbf{3 0}$ menit dan ditimbang ketika mencapai suhu ruang (A). Sampel ditimbang sebanyak \pm 2 g dalam cawan (B). Cawan beserta isi dikeringkan dalam oven vakum pada suhu 95-100oC selama 6 jam, 


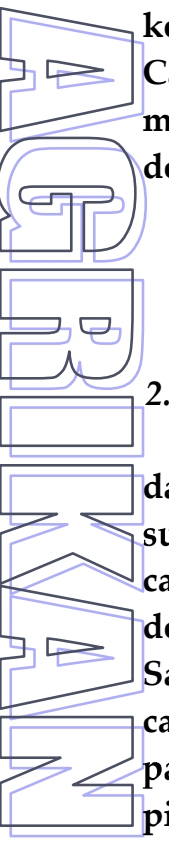

kondisi vakum pada tekanan $\leq 100 \mathrm{mmHg}$. Cawan dipindahkan ke dalam desikator $\pm \mathbf{3 0}$ menit lalu didinginkan dan ditimbang (C), dengan perhitungan:

$$
\% \text { Kadar air }=\frac{B-C}{B-A} \times 100 \%
$$

\subsubsection{Kadar Abu (SNI 01-2354.1-2006)}

Cawan porselin kosong dimasukkan dalam tungku pengabuan, dipanaskan pada suhu 550 :C selama 1 malam, selanjutnya cawan dikeluarkan dan didinginkan dalam desikator selama 30 menit dan ditimbang (A). Sampel sebanyak 2 g dimasukkan ke dalam cawan porselin, dihomogenkan dengan oven pada suhu 100 a selama 24 jam, kemudian pindahkan ke tungku pengabuan pada suhu $550 \stackrel{4}{*} \mathrm{C} \quad 5$, selama 8 jam hingga memperoleh abu berwarna putih, cawan didinginkan di dalam desikator selama 30 menit dan ditimbang (B). Pengujian dilakukan duplo, kemudian dilakukan perhitungan:

$$
\% \text { Kadar abu }=\frac{\mathrm{B}-\mathrm{A}}{\text { Berat sampel }} \times 100 \%
$$

2.3.3. Protein Metode Mikro Abu Kjeldahl (SNI 01-2354.4-2006)

Tahap-tahap yang dilakukan dalam analisis protein terdiri dari tiga tahap yaitu destruksi, destilasi, dan titrasi. Pengukuran kadar protein dilakukan dengan metode kjeldahl. Sampel sebanyak 2 g ditimbang, kemudian dimasukkan ke dalam labu kjeldahl $50 \mathrm{ml}$, lalu ditambahkan 7 g K2SO4, kjeltab $0.005 \mathrm{~g}$ jenis $\mathrm{HgO}$ dan $15 \mathrm{ml} \mathrm{H} 2 \mathrm{SO} 4$ pekat dan $10 \mathrm{ml} \mathrm{H2O} 2$ ditambahkan secara perlahan ke dalam labu dan didiamkan 10 menit di ruang asam. Sampel didestruksi pada suhu 410 oC selama \pm 2 jam atau sampai larutan bening, diamkan hingga mencapai suhu kamar dan ditambahkan dengan akuades 50-75 $\mathrm{ml}$, dan larutan tersebut dimasukkan ke dalam alat destilasi. Hasil destilasi ditampung dalam erlenmeyer $125 \mathrm{ml}$ yang berisi $25 \mathrm{ml}$ asam borat (H3BO3) 4\% yang mengandung indikator bromcherosol green $0.1 \%$ dan methyl red $0.1 \%$ dengan perbandingan 2:1. Destilasi dilakukan dengan menambahkan $50 \mathrm{ml}$ larutan $\mathrm{NaOH}-$ $\mathrm{Na2S2O3}$ ke dalam alat destilasi hingga tertampung $150 \mathrm{ml}$ destilat di dalam erlenmeyer dengan hasil destilat berwarna hijau. Lalu destilat dititrasi dengan $\mathrm{HCl} 0.2 \mathrm{~N}$ sampai terjadi perubahan warna merah muda yang pertama kalinya. Volume titran dibaca dan dicatat. Larutan blanko dianalisis seperti contoh. Kadar protein dihitung dengan rumus sebagai berikut:

$$
\begin{gathered}
\% \mathrm{~N}=\{(\mathrm{mL} \mathrm{HCl}-\mathrm{mL} \text { blanko }) \times \mathrm{N} \mathrm{HCl} \times 14.007 \times \\
100 \%] / \mathrm{mg} \text { contoh } \\
\% \text { Protein }=\% \mathrm{~N} \times \text { faktor konversi }{ }^{*} \\
\text { *) FK }=6.25
\end{gathered}
$$

\subsubsection{Kadar Lemak Total (SNI 01-2354.3.2006)}

Labu lemak kosong ditimbang (A). Sampel sebanyak \pm 2 g sampel (B) dalam kertas saring dimasukkan ke dalam selongsong lemak. Pelarut $150 \mathrm{ml}$ Chloroform dituangkan ke dalam labu soxhlet, kemudian bersama selongsong lemak dipasang ke dalam extractor soxhlet dengan benar. Ekstraksi dilakukan pada suhu 60 就 selama 8 jam hingga kering labunya. Labu lemak berisi lemak dikeringkan dalam oven suhu 105 oC selam \pm 2 jam untuk menghilangkan sisa chloroform dan uap air. Labu lemak didinginkan dalam desikator \pm 30 menit dan ditimbang $(C)$, dengan perhitungan.

$$
\% \text { Kadar lemak }=\frac{\mathrm{C}-\mathrm{A}}{\mathrm{B}} \times 100 \%
$$

\subsubsection{Kadar Karbohidrat}

Karbohidrat dihitung berdasar metode by difference dengan perhitungan :

$\%$ Kadar karbohidrat $=100-$ jumlah kadar air,abu,protein dan lemak

\subsubsection{Evaluasi Sensori (SNI 01-2346-2006)}

Evaluasi sensori dilakukan menggunakan skala hedonik untuk menentukan tingkat kesukaan dengan membandingkan produk yang diuji secara langsung. Evaluasi sensori dilakukan menggunakan indra manusia sebagai alat utama untuk menilai produk yang di uji yang dilakukan sedikitnya 25-30 orang panelis tidak terstandar. Uji hedonik adalah penilaian contoh yang diuji berdasarkan tingkat kesukaan panelis. Jumlah tingkat kesukaan bervariasi 


\begin{tabular}{|l} 
tergantung dari rentangan mutu yang \\
ditentukan. Penilaian diubah dalam $\begin{array}{r}\text { (duplo), sedangkan data } \\
\text { bentuk }\end{array}$ \\
angka dan dianalisis secara statistik untuk \\
penarikan kesimpulan \\
(Sugiyono, 2015).
\end{tabular}

Ket: pelakuan penambahan tepung tapioka $A_{1}(0 \%), A_{2}$ (5\%), $A_{3}(10 \%)$, dan $A_{4}(15 \%)$

\subsubsection{Kadar Air}

Kadar air adalah persentase kandungan air suatu bahan pangan yang keberadaannya mempengaruhi stabilitas dan keawetan pangan (Kusnandar, 2010). Kadar air nugget berkisar antara 48.98-54.58\% (Tabel 1), dengan nilai tertinggi pada perlakuan A4 $(15 \%$ tepung tapioka) dan terendah pada perlakuan A1 $(0 \%$ tepung tapioka). Hal ini menunjukkan bahwa makin besar konsentrasi tepung tapioka yang ditambahkan meningkatkan kadar air nugget yang dihasilkan.

Hasil ini berbeda penelitian Restu (2012), yang menyatakan bahwa makin tinggi konsentrasi tepung tapioka makin rendah kandungan air yang terdapat dalam produk nugget ikan toman. Kadar air nugget daging merah ikan madidihang lebih tinggi dari kadar air nugget tetelan merah tuna berkisar antara $36.49-50.23 \%$ (Wellyalina et al., 2013) dan kadar air tersebut masih memenuhi standar mutu maksimal kadar air pada nugget ikan yaitu $80 \%$ (SNI, 2013).

\subsubsection{Kadar Abu}

Kadar abu dalam bahan pangan digunakan sebagai indikator jumlah elemen mineral pada suatu bahan (Estiasih et al., 2015). Kadar abu nugget pada penelitian berkisar antara $1.98-4.49 \%$ (Tabel 1) dan hasilnya menunjukkan bahwa makin besar konsentrasi tepung tapioka yang ditambahkan, menurunkan kadar abu nugget. Kadar abu tertinggi terdapat pada perlakuan A1 $(0 \%$ tepung tapioka) dan terendah pada perlakuan A4 (15\% tepung tapioka). Makin rendahnya kandungan abu pada nugget dengan konsentrasi tapioka yang tinggi, diduga akibat dari kandungan mineral tepung tapioka lebih sedikit dibandingkan pada daging ikan, sehingga penambahan konsentrasi tepung tapioka mengakibatkan penurunan kadar abu. Hasil yang sama juga diperoleh oleh Wellyalina et al., (2013) yang menunjukkan kadar abu nugget tetelan merah tuna mengalami penurunan seiring dengan bertambahnya konsentrasi tepung maizena dengan kisaran nilai $0.73-1.14 \%$.

\subsubsection{Kadar Protein}

Kadar protein dalam bahan pangan merupakan persentase nitrogen yang dikalikan dengan nilai konversi 6.25 berdasarkan asumsi jumlah nitrogen dalam protein sebesar $16 \%$ (Kusnandar, 2010). Kadar protein nugget berkisar antara $13.71-17.61 \%$ (Tabel 1), dengan nilai tertinggi pada perlakuan A1 $(0 \%$ tepung tapioka) dan terendah pada perlakuan A4 (15\% tepung tapioka). Kadar protein nugget mengalami penurunan seiring dengan peningkatan konsentrasi tepung tapioka yang ditambahkan. Hasil yang sama juga ditunjukkan pada nugget ikan toman dengan penambahan tapioka $5-15 \%$ dengan nilai antara 
12.23-15.89\% (Restu, 2012) dan nugget tetelan merah tuna yang menggunakan maizena 5-25\% dengan kisaran nilai 9.67-16.10\% (Wellyalina et al., 2013).

3.1.4. Kadar Lemak

Kadar lemak nugget berkisar antara 9.78$12.46 \%$ (Tabel 1), dengan nilai tertinggi pada perlakuan A1 (0\% tepung tapioka) dan terendah pada perlakuan A4 (15\% tepung tapioka). Hasil ini menunjukkan bahwa semakin besar konsentrasi tepung tapioka yang digunakan dalam pembuatan nugget ikan, semakin rendah kadar lemak nugget ikan. Kadar lemak nugget ikan selain dari daging merah ikan, juga berasal dari kuning telur (32.2\%) dan minyak nabati yang digunakan pada proses penggorengan. Kadar lemak nugget pada penelitian ini lebih tinggi dari kadar lemak nugget menggunakan tetelan merah tuna dengan tepung maizena yaitu 7.80-11.03\% (Wellyalina et al., 2013).

3.1.5. Kadar Karbohidrat

Kadar karbohidrat nugget berkisar antara 16.46-19.95\% (Tabel 1) dengan nilai tertinggi pada perlakuan A4 (15\% tepung tapioka) dan terendah pada perlakuan A1 $(0 \%$ tepung tapioka). Hasil ini menunjukkan bahwa makin besar konsentrasi tepung tapioka digunakan dalam pembuatan nugget meningkatkan kadar karbohidrat nugget ikan. Kadar karbohidrat

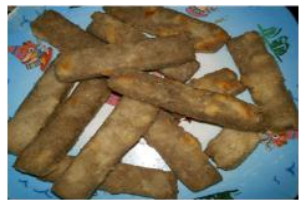

A1 (0\% Tapioka)

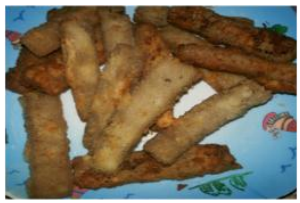

$\mathrm{A}_{2}$ (5\% Tapioka) nugget pada penelitian ini lebih rendah dari karbohidrat pada nugget tetelan merah tuna yaitu 21.58-45.03\% (Wellyalina et al., 2013).

Kandungan karbohidrat pada produk nugget berasal dari tepung tapioka yang digunakan sebagai bahan pengikat dalam pembuatan nugget dan salah satu sifat fungsional tepung tapioka membantu proses pembentukan gel dengan cara mengikat air selama proses pengadonan dan pengukusan.

\subsection{Evaluasi Sensori}

Evaluasi sensori adalah bentuk uji menggunakan indra manusia sebagai instrumen pengujiannya, yang diwakili oleh panelis untuk menilai tentang sifat dan mutu benda atau bahan (Soekarto, 1985). Evaluasi sensori merupakan bentuk pengujian fisiopsikologis yang mana secara sadar menggunakan panca indra untuk menentukan sifat benda secara subjektif karena adanya rangsangan dari benda yang tertangkap oleh indra. Setiap individu akan memberi respon berbeda terhadap rangsangan yang sama karena memiliki tingkat sensitivitasi organ pengindraa yang berbeda (Setyahningsih et al., 2010). Bentuk fisik nugget daging merah ikan madidihang terlihat pada Gambar 1 dan hasil evaluasi sensori seperti pada Gambar 1.
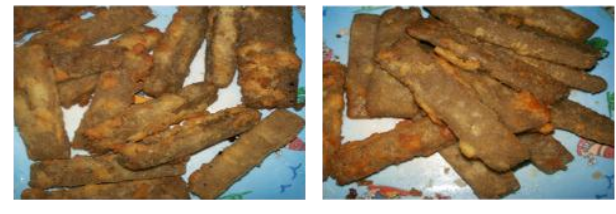

$A_{3}$ (10\% Tapioka)

Gambar 1. Nugget Daging Merah Ikan Madidihang

\subsubsection{Tekstur}

Tekstur merupakan faktor penting dalam menentukan mutu makanan dan dapat digunakan acuan untuk pengujian fisik dan kadar air (de Man, 1997). Evaluasi sensori atribut tekstur nugget berkisar antara 5.00-5.72 (Tabel 2) dengan nilai tertinggi pada perlakuan A1 (0\% tepung tapioka) dan terendah pada perlakuan A4 (15\% tepung tapioka). Hasil ini menunjukkan bahwa semakin besar penambahan konsentrasi tepung tapioka menurunkan tingkat kesukaan panelis terhadap atribut tekstur nugget ikan, karena semakin besar jumlah tepung tapioka yang ditambahkan mengakibatkan tektur nugget menjadi agak keras dan tidak kenyal.

Analisis statistik atribut tekstur nugget menunjukkan nilai chi square yaitu 8.764 dan asymp sig 0.033 artinya penambahan konsentrasi tepung tapioka berpengaruh nyata terhadap tingkat kesukaan tekstur nugget. Hal ini menunjukkan bahwa penambahan konsentrasi tepung tapioka yang berbeda menghasilkan nugget dengan tekstur yang 
berbeda pula. Hasil rangking menunjukkan nugget A1 (2.86) mendapat respon yang paling tinggi, diikuti oleh nugget A3 (2.62), kemudian A2 (2.54) dan A4 (1.98).

Tabel 2. Evaluasi sensori nugget daging merah ikan madidihang

\begin{tabular}{lcccc}
\hline Atribut Sensori & $\mathrm{A}_{1}$ & $\mathrm{~A}_{2}$ & $\mathrm{~A}_{3}$ & $\mathrm{~A}_{4}$ \\
\hline \hline Tekstur & $5.72 \pm 0.614$ & $5.52 \pm 0.872$ & $5.52 \pm 1.046$ & $5.00 \pm 1.118$ \\
Warna & $5.40 \pm 0.913$ & $5.52 \pm 1.122$ & $5.32 \pm 1.069$ & $4.80 \pm 1.118$ \\
Aroma & $5.84 \pm 0.987$ & $6.00 \pm 1.000$ & $5.52 \pm 0.872$ & $5.24 \pm 1.200$ \\
Rasa & $6.36 \pm 0.757$ & $6.28 \pm 0.792$ & $5.84 \pm 1.028$ & $5.68 \pm 1.108$ \\
\hline
\end{tabular}

Ket: pelakuan penambahan tepung tapioka $A_{1}(0 \%), A_{2}(5 \%), A_{3}(10 \%)$, dan $A_{4}(15 \%)$

Ukuran serat daging merah ikan umumnya lebih kecil dibandingkan serat daging putih, sehingga ketika ditambahkan bahan pengikat dalam jumlah yang banyak dicampur dengan air es menghasilkan produk bertekstur kenyal dan padat. Sifat tekstur juga dipengaruhi oleh pembentukan gel protein kolagen dan sarkoplasma (Zayas, 1997).

\subsubsection{Warna}

Warna berperan penting dalam aspek penerimaan dan memilih makanan, selain itu, warna dapat menjadi indikator perubahan kimia dalam makanan (de Man, 1997). Evaluasi sensori atribut warna nugget berada pada kisaran 4.80-5.52 (Tabel 2.) dengan nilai tertinggi terdapat pada perlakuan $A_{1} \quad(0 \%$ tepung tapioka) dan terendah pada perlakuan A4 (15\% tepung tapioka).

Analisis statistik atribut warna nugget menunjukkan nilai chi square 11.478 dan asymp sig 0.009 artinya penambahan konsentrasi tepung tapioka berpengaruh nyata terhadap tingkat kesukaan warna nugget. Hasil ini menunjukkan bahwa penambahan konsentrasi tepung tapioka yang berbeda akan menghasilkan nugget dengan warna yang berbeda. Hasil rangking menunjukkan nugget $A_{2}$ (3.02) mendapat respon yang paling tinggi, diikuti oleh nugget $\mathrm{A}_{3}$ (2.60), A1 (2.38) dan $\mathrm{A}_{4}$ (2.00).

Warna nugget ikan pada penelitian ini lebih rendah dibandingkan warna nugget ikan toman (Restu, 2012). Nugget daging merah ikan madidihang berwarna kecoklatan, yang disebabkan karena daging merah mengandung protein myoglobin dan hemoglobin, yang merupakan jenis protein ini memiliki gugus heme sehingga ketika, daging dimasak mengakibatkan protein globulin terkoagulasi sehingga gugus heme terbuka yang menyebabkan terjadi proses oksidasi membentuk hemin.

\subsubsection{Aroma}

Aroma khas nugget ikan adalah harum daging ikan, akan tetapi pada nugget daging merah tanpa penambahan tepung tapioka masih tercium aroma amis yang disebabkan oleh trimetilamin pada otot daging merah lebih dominan. Ikan yang banyak mengandung lemak dan mengandung pro-oksidan dapat merupakan penyebab utama perubahan aroma/odor daging ikan (Hadiwiyoto, 1993; Ilyas, 1993).

Evaluasi sensori atribut aroma nugget berkisar antara 5.24-6.00 (Tabel 2), dengan nilai tertinggi pada perlakuan $\mathrm{A}_{1} \quad(0 \%$ tepung tapioka) dan terendah pada perlakuan A4 (15\% tepung tapioka). Analisis statistik atribut aroma nugget menunjukkan nilai chi square 8.371 dan asymp sig 0.039 artinya penambahan konsentrasi tepung tapioka berpengaruh nyata terhadap tingkat kesukaan aroma nugget yang menunjukkan bahwa konsentrasi tepung tapioka yang berbeda mengakibatkan perbedaan aroma nugget. Hasil rangking menunjukkan nugget $\mathrm{A}_{2}$ (2.96) mendapat respon yang paling tinggi, diikuti oleh nugget $\mathrm{A}_{1}$ (2.68) kemudian $\mathrm{A}_{2}$ (2.28) dan $\mathrm{A}_{4}$ (2.08).

\subsubsection{Rasa}

Rasa pangan adalah faktor kedua, yang mempengaruhi cita rasa pangan setelah kenampakan produk pangan itu sendiri. Rasa merupakan tanggapan atas adanya rangsangan kimiawi yang sampai di indera pengecap lidah, khususnya jenis rasa dasar manis, asin, asam dan pahit (Winarno, 2008).

Evaluasi sensori atribut rasa nugget memiliki kisaran nilai antara 5.68-6.36 (Tabel 2), dengan nilai tertinggi terdapat pada perlakuan A1 (0\% tepung tapioka) dan terendah pada perlakuan $\mathrm{A}_{4}$ (15\% tepung tapioka). Analisis 
statistik atribut rasa nugget menunjukkan nilai chi square 6.492 dan asymp sig 0.090 artinya penambahan konsentrasi tepung tapioka tidak berpengaruh terhadap tingkat kesukaan rasa nugget. Hasil ini menunjukkan bahwa penambahan tepung tapioka pada konsentrasi tertentu tidak mempengaruhi respon penilaian atribut rasa nugget ikan. Hasil rangking menunjukkan nugget $A_{1}$ (2.82) mendapat respon yang paling tinggi, kemudian $A_{2}$ (2.74), $\mathrm{A}_{3}$ (2.22) dan $\mathrm{A}_{4}$ (2.22).

Hasil ini berbeda dengan hasil penelitian Kumalasari (2002), yang menyatakan bahwa makin sedikit penambahan tepung tapioka maka rasa ikan akan semakin terasa. Produk nugget hasil penelitian ini memiliki rasa ikan dan gurih, dan hasilnya sama dengan nugget ikan lainnya. Cita rasa gurih (umami) pada produk nugget dipengaruhi oleh asam inosinat asam inosinat dan guanosine monophosphate yang terdapat pada daging ikan (Winarno, 2008).
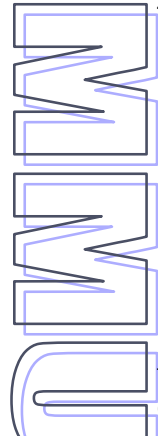

Amrullah. 2004. Analisa Bahan Pangan. Universitas Hasanudin. Makasar.

de Man JM. 1997. Kimia Makanan. Penerbit ITB. Bandung.

Estiasih T, Putri WDR, Widyastuti E. 2015. Komponen Minor dan Bahan Tambahan Pangan. Bumi Aksara. Jakarta.

Hadiwiyoto S. 1993. Pengawetan dan Pengolahan Hasil Perikanan. Penerbit Swadaya. Jakarta.

Hanafiah KA. 2014. Rancangan Percobaan Teori dan Aplikasi. Ed. 3 Cetakan 15. Rajawali Press. Jakarta

Ilyas S. 1993. Teknologi Refrigerasi Hasil Perikanan. Jilid II. Teknik Pembekuan Ikan. Penerbit CV Paripurna. Jakarta.

Kim SK, Mendis E. 2006. Bioactive compounds from marine processing by product - A review. Food Research Intl. 39 pp. 383-393

Kusnandar F. 2010. Kimia Pangan-Komponen Makro. Dian Rakyat. Jakarta

Learson RJ, Kaylor JD. 1990. Pelagis Fish dalam Industri Makanan. Editor RE Martin dan GJ Flick. Van Nastrand. New York

Restu. 2012. Pemanfaatan Ikan Toman (Channa micropeltes) Sebagai Bahan Nugget. Jurnal Ilmu Hewani Tropika.Vol 1(2) pp. 67-70

Sánchez-Zapata et al., 2011. Quality Characteristics of Dark Muscle from Yellowfin Tuna (Thunnus albacares) to Its Potential Application in the Food Industry. Food and Nutrition Sciences 2011 (2) pp. 22-30. doi:10.4236/ fns.2011.21003

Setyaningsih, Apriyantono, Puspita. 2010. Analisis Sensori. Penerbit IPB Press. Bogor

SNI [Standar Nasional Indonesia]. 2006. SNI: 012346-2006. Petunjuk Pengujian Organoleptik dan Sensorik. Badan Standar Nasional Indonesia. Jakarta 
SNI [Standar Nasional Indonesia]. 2006. SNI: 01-2354.1-2006. Cara Uji Kimia Bagian 1: Penentuan Kadar Abu Pada Produk Perikanan. ICS. 67.120.30 Badan Standar Nasional Indonesia. Jakarta

SNI [Standar Nasional Indonesia]. 2006. SNI: 01-2354.2-2006. Cara Uji Kimia Bagian 2: Penentuan Kadar Air Pada Produk Perikanan. ICS. 67.120.30 Badan Standar Nasional Indonesia. Jakarta.

SNI [Standar Nasional Indonesia]. 2006. SNI: 01-2354.3-2006. Cara Uji Kimia Bagian 3: Penentuan Kadar Lemak Pada Produk Perikanan. ICS. 67.120.30 Badan Standar Nasional Indonesia. Jakarta.

SNI [Standar Nasional Indonesia]. 2006. SNI: 01-2354.4-2006. Cara Uji Kimia Bagian 4: Penentuan Kadar Protein Pada Produk Perikanan. ICS. 67.120.30 Badan Standar Nasional Indonesia. Jakarta.

SNI [Standar Nasional Indonesia]. 2013. SNI: 7758-2013. Naget Ikan. ICS-67.120.30. Badan Standar Nasional Indonesia. Jakarta.

Soediaoetomo AJ. 2004. Ilmu Gizi dan Profesi untuk Mahasiswa. Dian Rakyat. Jakarta.

Soekarto ST. 1985. Penilaian Organoleptik untuk Industri Pangan dan Hasil Pertanian. Batara Karya Aksara. Jakarta

Sugiyono. 2015. Statistik Nonparametris untuk Penelitian. Penerbit Alfabeta. Bandung.

Suzuki T. 1981. Fish Krill Protein Processing Technology. Aplied Science Publisher Ltd. London.

Tjokroadikusumo PS. 1993. HFS dan Industri Ubi Kayu Lainnya. PT. Gramedia. Jakarta.

Wellyalina, Azima F, Aisman. 2013. Pengaruh Perbandingan Tetelan Merah Tuna dan Tepung Maizena Terhadap Mutu Nugget. Jurnal Aplikasi Teknologi Pangan Vol. 2 (1) pp. 9-17.

Winarno FG. 2008. Kimia Pangan dan Gizi. PT. Gramedia Pustaka Utama. Jakarta

Zayas JF. 1997. Functionally of Protein in Food. Springer. Germany

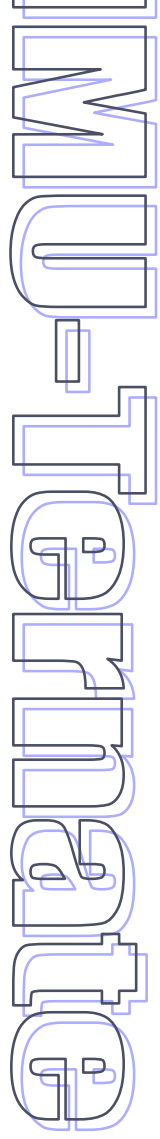

